\title{
ANATOMIA DO LENHO DE ESCULTURAS DO MUSEU VICENTE PALLOTTI (SANTA MARIA, RS, BRASIL). II - DESCRIÇÃO E IDENTIFICAÇÃO DE CINCO IMAGENS SACRAS ${ }^{1}$
}

\author{
PAULO FERNANDO DOS SANTOS MACHADO ${ }^{2}$ \\ JOSÉ NEWTON CARDOSO MARCHIORI ${ }^{3}$ DANIELI SANCHES ${ }^{4}$
}

\begin{abstract}
RESUMO
Os lenhos das esculturas intituladas Cabeça de Cristo, Nossa Senhora da Glória, Rei Mago, São José e São Roque, provenientes das Missões Jesuíticas do Rio Grande do Sul e integrantes do acervo do Museu Vicente Pallotti, de Santa Maria, RS, foram anatomicamente descritos, ilustrados e identificados como pertencentes a Cedrela fissilis Vell. (Meliaceae), o popular Cedro da flora regional. Entre os caracteres que levaram à identificação da espécie, salientam-se: parênquima em faixa marginal com 2-10 células de largura; poros solitários, de diâmetro médio a grande; placas de perfuração simples; raios heterogêneos com até 4 células de largura e 1-2 fileiras marginais de células quadradas; e fibras libriformes de paredes finas, não septadas. Palavras-chave: Anatomia da Madeira; Cedrela fissilis; Cabeça de Cristo; Cedro; Meliaceae; Missões Jesuíticas; Nossa Senhora da Glória; Rei Mago; Rio Grande do Sul; São José; São Roque.
\end{abstract}

\section{ABSTRACT}

[Wood anatomy of Vicente Pallotti Museum sculptures (Santa Maria, RS, Brazil). II - Description and identification of the wood of five sacred images].

Coming from the Jesuitic Missions of Rio Grande do Sul State and preserved in Vicente Pallotti Museum (Santa Maria, RS), the wood of the sculptures entitled Head of Christ, Our Lady of Glory, King Magus, St. Joseph and St. Roch were anatomically described, illustrated and identified as belonging to Cedrela fissilis Vell., a Meliaceae called Cedar in Brazil. Among the characters that led to the identification of the species, we highlight: axial parenchyma in a marginal band with 2-10 cells wide; mostly solitary vessels with medium to large diameter; simple perforation plates; heterogeneous rays up to four cells wide and with 1-2 marginal rows of square cells; and non-septate thin walled libriform fibers.

Key words: Cedar; Cedrela fissilis; Head of Christ; Jesuitic Missions; King Magus; Meliaceae; Our Lady of Glory; Rio Grande do Sul State; Spanish Cedar; St. Joseph; St. Roch; Wood Anatomy.

\section{INTRODUÇÃO E REVISÃO DE LITERATU- RA}

A identificação anatômica de amostras de madeira permite acesso a informações valiosas, constantes na literatura, e que ajudam a esclarecer questões de interesse para vários ramos da ciência, tecnologia e conhecimento humano, casos da Arqueologia e História.

1 Recebido em 25-05-2018 e aceito para publicação em 07-8-2018

2 Engenheiro Florestal, doutorando do Programa de PósGraduação em Engenharia Florestal, Universidade Federal de Santa Maria, RS, Brasil. barcasole@gmail.com

3 Engenheiro Florestal, Dr. Professor Titular do Departamento de Ciências Florestais, Universidade Federal de Santa Maria.marchiori@pq.cnpq.br
Apesar de sua importância para a História Regional, ainda são escassas as investigações anatômicas sobre o acervo missioneiro do Rio Grande do Sul (Schulze-Hofer \& Marchiori, 2008), salientando-se os estudos sobre quatro imagens do Museu das Missões ${ }^{5}$, bem como sobre uma das mísulas do alpendre do Colégio de São Luiz Gonzaga (Schulze-Hofer \& Marchiori, 2009), de um pilar do Colégio de São

\footnotetext{
4 Historiadora. Responsável Técnica pelo Museu Vicente Pallotti.museu_pallotti@terra.com.br

5 São elas: a escultura de São José (Marchiori \& SchulzeHofer, 2009a); de São Lourenço Mártir (Marchiori \& Schulze-Hofer, 2009c); de Santo Estanislau Kostka (Marchiori \& Schulze-Hofer, 2010b); e de Nossa Senhora das Dores (Schulze-Hofer \& Marchiori, 2010).
} 
Miguel Arcanjo (Marchiori \& Schulze-Hofer, 2010a) e de um fragmento de madeira obtido em escavação arqueológica no átrio da igreja de São Lourenço (Marchiori \& Schulze-Hofer, 2009b). Nestas pesquisas, comprovou-se que as esculturas de São Lourenço Mártir, Santo Estanislau Kostka e Nossa Senhora das Dores foram realizadas em madeira de cedro (Cedrela fissilis), ao passo que a de São José foi feita em pinheiro-brasileiro (Araucaria angustifolia); provou-se, igualmente, que tanto na referida mísula como no fragmento procedente de escavação arqueológica usou-se madeira de ipê-roxo (Handroanthus heptaphyllus), e que o pilar do Colégio de São Miguel Arcanjo é de ipê-amarelo (Handroanthus pulcherrimus).

Em estudo de três esculturas do Museu Sacro de Santa Maria (Nossa Senhora Missioneira, Santo Antônio de Pádua e Senhor dos Passos), Marchiori \& Machado (2017) comprovaram que todas foram realizadas em madeira de cedro (Marchiori \& Machado, 2017).

No tocante ao riquíssimo acervo do Museu Vicente Pallotti (Santa Maria, RS), a investigação anatômica do "Menino" mostrou que a obra foi executada em madeira de Tilia sp. (Malvaceae, ex Tiliaceae), comprovando sua procedência européia, não americana.

Sob o ponto de vista anatômico, a madeira de Cedrela fissilis, embora carente de traços singulares, pode ser reconhecida na flora euxilófora sul-americana pelo seguinte conjunto de caracteres: parênquima axial em faixa marginal com 2-10 células de largura, menos conspicuamente paratraqueal escasso e apotraqueal difuso; vasos arredondados ou ovais, de diâmetro médio a grande; placas de perfuração simples; pontoações intervasculares alternas, não ornamentadas; pontoações raio-vasculares e parênquimo-vasculares, semelhantes às intervasculares, embora menores; raios heterogêneos, com células procumbentes e 1-2 fileiras marginais de células quadradas; e fibras libriformes não septadas, de paredes finas (Araújo, 1948; Mainieri \& Chimelo, 1089; Marchiori et alii, 2009; Tortorelli, 1956; Tuset \& Duran, 1970).
A respeito do nome comum, a espécie é dita Cedro, em português (Backes \& Nardino, 2001), e Cedar ou Spanish Cedar, em inglês (Record \& Hess, 1943).

No presente trabalho, que visa a agregar conhecimento científico e, por conseguinte, a valorização de bens tombados do Patrimônio Histórico e Artístico Nacional, são descritos, ilustrados e identificados os lenhos de cinco imagens missioneiras, integrantes do acervo do Museu Vicente Pallotti.

\section{MATERIAL E MÉTODOS}

O material investigado consiste de um fragmento de lenho de cada uma das imagens em estudo, extraído de local especialmente escolhido com vistas a não comprometer a estética da peça. Tanto as amostras como o local de extração das mesmas são indicadas nas pranchas relativas a cada escultura (Figuras 1, 3, 5, 7 e 9).

Com vistas à microtomia, foram obtidos três corpos-de-prova de cada fragmento de lenho coletado, orientados para a obtenção de cortes nos planos transversal, longitudinal radial e longitudinal tangencial. Os corpos-de-prova foram fervidos em água até a expulsão completa do ar e, na sequência, seccionados em micrótomo de deslize (Leica), no Laboratório de Anatomia da Madeira, do Departamento de Ciências Florestais da Universidade Federal de Santa Maria (UFSM). Os cortes, com espessura nominal de 18-26 $\mu \mathrm{m}$, foram coloridos com "Safrablau", desidratados em série alcoólica crescente $(25 \%$, $50 \%, 75 \%, 90 \%, 95 \%$ ), até álcool absoluto, passaram por xilol e foram montados em lâminas permanentes, usando-se "Entellan" como resina.

Não foram feitas lâminas de macerado, uma vez que a pesquisa não pretende realizar uma descrição formal das madeiras, mas uma simples identificação das mesmas. As imagens das Figuras 2, 4, 6, 8 e 10 foram obtidas em fotomicroscópio Leica DM 2000, equipado com câmera digital Leica DCF 295, no Laboratório de Botânica Estrutural, do Departamento de Biologia da UFSM. 
Na citação de valores quantitativos da estrutura anatômica, o valor que acompanha a média é o desvio padrão (média \pm desvio padrão); os números seguintes, entre parênteses, correspondem aos valores mínimos e máximos observados.

Para a identificação das amostras de madeira foram consultadas as obras anatômicas listadas em "Referências Bibliográficas".

\section{IDENTIFICAÇÃO DOS LENHOS}

As cinco imagens presentemente investigadas são, a seguir, anatomicamente descritas e identificadas, após breve caracterização museológica, elaborada com base nas fichas de Danieli Sanches, datadas de 07/12/2017 e com dados extraídos do "Inventário da Imaginária Missioneira" (MinC/IPHAN-12 ${ }^{\mathrm{a}} \mathrm{CR}$ ).

\section{1 - Cabeça de Cristo}

De oficina jesuítica (Missões do Rio Grande do Sul) e atribuída ao século XVII-XVIII, a "Cabeça de Cristo" integra o acervo do Museu Vicente Pallotti (MVP.06.3307), é bem tombado pelo IPHAN (RS/90.001.0236) e se encontra exposta na sala 09 do referido Museu. Consta que a imagem veio do "Lar das Vovozinhas" (Santa Maria) em data desconhecida, por doação de Serafina Soares da Silva.

Feita em madeira policromada $(48,5 \mathrm{~cm}$ de altura, $40 \mathrm{~cm}$ de largura e $17 \mathrm{~cm}$ de profundidade), representa uma figura masculina de fisionomia jovem, rosto oval, cabelos longos, em mechas e bipartidos ao meio, bigode aparado, bipartido e juntando-se à barba, olhos grandes, amendoados, sobrancelhas arqueadas, nariz aquilino, boca fechada e lábios grossos (Figura 1A). A obra denota certo primitivismo, sobretudo pelos traços acentuados do nariz e boca (Figura 1A, B). A respeito do estado de conservação, destacam-se sinais do ataque de insetos xilófagos e resquícios de policromia.

A amostra de lenho (Figura 1D, E) foi extraída da ponta dos cabelos (seta), no lado esquerdo da peça (Figura 1B, C).
Descrição anatômica:

Anéis de crescimento distintos, marcados por faixas de parênquima marginal com 4-8 células de largura (Figura 2A, B).

Vasos: arredondados ou ovais, de diâmetro médio a grande (279 $\pm 70(150-388) \mu \mathrm{m})$, solitários ou em curtos múltiplos radiais (Figura 2A, B). Elementos vasculares com placas de perfuração simples, transversais (Figura $2 \mathrm{~F}$ ) ou oblíquas (Figura 2E). Pontoações intervasculares arredondadas $(6,9 \pm 0,9(5,2-8,2 \mu \mathrm{m}) \mathrm{e}$ em arranjo alterno (Figura 2E, F). Pontoações raio-vasculares e parênquimo-vasculares, semelhantes às intervasculares, embora menores; as primeiras, de 5,8 $\pm 0,6(5,2-6,7) \mu \mathrm{m})$; as últimas, de 6,2 $\pm 1,4(4,1-8,0) \mu \mathrm{m}$ (Figura 2C). Conteúdo, com aspecto de gomo-resina, evidente em vasos (Figura 2A).

Parênquima axial: em faixas marginais aos anéis de crescimento, bem como paratraqueal (Figura 2B) e apotraqueal difuso (Figura 2A).

Raios: heterocelulares, compostos de células procumbentes e com 1-2 fileiras marginais de células quadradas (Figura 2C, D). Células radiais de contorno arredondado, em plano tangencial (Figura 2E, F). Raios de $289 \pm 84$ (163-425) $\mu \mathrm{m}$ de altura, com $13 \pm 3,7$ (6-20) células, e $56 \pm 12(25-75) \mu \mathrm{m}$ de largura, com $3,6 \pm 0,7$ (2-4) células (Figura 2E, F). Deterioração, evidente em cortes tangenciais (Figura 2E, F), pela destruição de células.

Fibras: libriformes, não septadas e de paredes delgadas (Figura 2C, D, E).

Outros caracteres: variantes cambiais, tubos lacticíferos e taniníferos, células oleíferas, células mucilaginosas, estratificação e máculas medulares, ausentes. Canais intercelulares, não observados.

Análise da estrutura anatômica

A larga faixa marginal de parênquima, juntamente com poros de diâmetro médio a grande, raios heterogêneos com 1-2 fileiras marginais de células quadradas, e fibras libriformes não septadas e de paredes finas, permitem iden- 

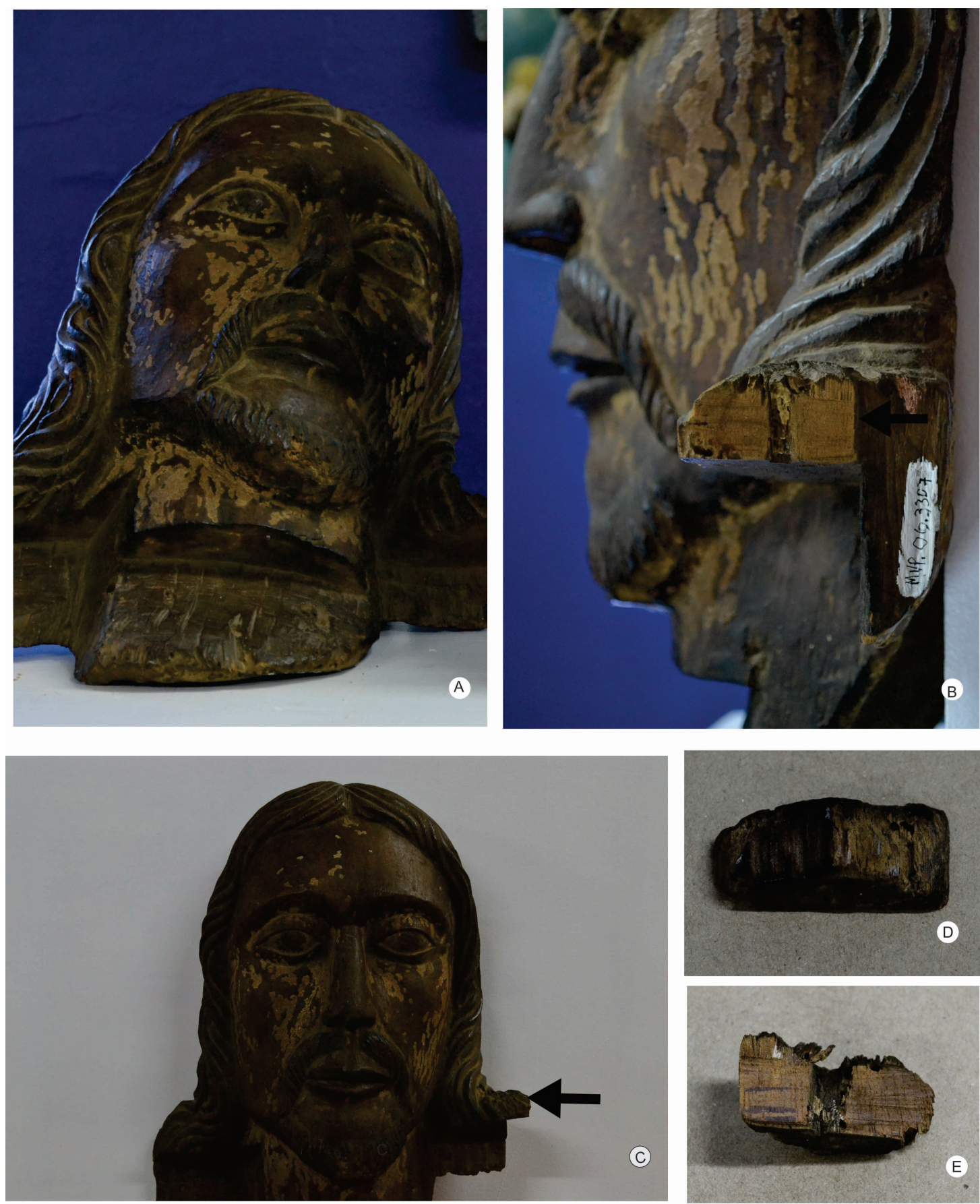

FIGURA 1 - Cabeça de Cristo. A - Vista de frente. B - Vista lateral, salientando o número de registro no Museu Vicente Pallotti e o local de extração da amostra de lenho (seta). C - Vista de frente; a seta indica o local de coleta da amostra. D, E - Dois aspectos da amostra coletada. 

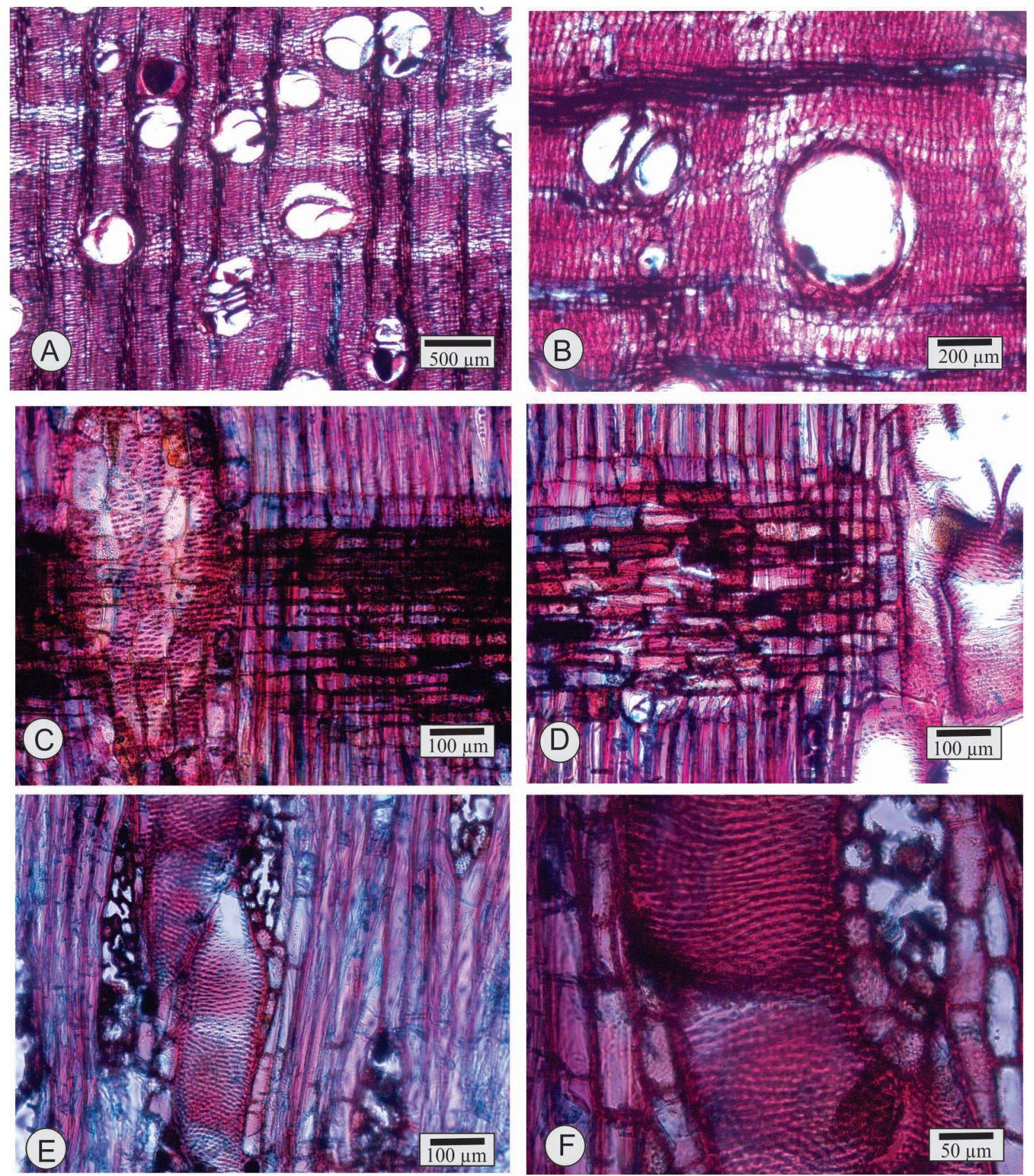

FIGURA 2 - Cabeça de Cristo; aspectos microscópicos do lenho. A, B - Faixas de parênquima marginal, além de parênquima paratraqueal e apotraqueal escasso; e vasos solitários ou em curtos múltiplos, com gomo-resina (Figura 2A) em dois deles (seção transversal). C - Fibras de paredes delgadas, pontoações parênquimo-vasculares e raio heterogêneo (seção radial). D - Mesmo plano anatômico da foto anterior, destacando fileira de células quadradas em ambas as margens de raios heterogêneos. E, F - Pontoações intervasculares, fibras de paredes delgadas e raios com indícios de deterioração (seção tangencial). 
tificar a amostra examinada como sendo de Cedrela fissilis Vell. (Meliaceae), o popular Cedro da flora sul-brasileira (Backes \& Nardino, 2001), uma vez que este conjunto de caracteres corresponde ao descrito para a referida espécie, por Araújo (1948), Mainieri \& Chimelo (1989), Marchiori et al. (2009), Tortorelli (1956) e Tuset $\&$ Duran (1970), entre outros autores.

\section{2 - Nossa Senhora da Glória}

Exposta na sala 09 do Museu Vicente Pallotti, a imagem em madeira policromada de Nossa Senhora da Glória consta no acervo com o registro MVP.06.3310 e foi tombada pelo IPHAN sob o número RS/90.0001.0227. Datada do século XVII/XVIII e oriunda de oficina jesuítica, provavelmente do Rio Grande do Sul, a peça foi recebida por doação, de cedente e em data desconhecidos, sabendo-se, apenas, que veio de Cruz Alta. Com $135 \mathrm{~cm}$ de altura, $70 \mathrm{~cm}$ de largura e $38 \mathrm{~cm}$ de profundidade, mostra figura feminina de corpo inteiro, em pé e posição frontal, com cabeça ligeiramente inclinada para cima, longos cabelos em estrias, repartidos ao meio e caídos nas costas, sobrancelhas arqueadas, nariz fino, boca entreaberta, pescoço fino, braços flexionados em ângulo, mãos postas no peito e perna esquerda levemente flexionada (Figura 3A). Veste túnica com cinto e manto esvoaçante sobre o ombro direito, que envolve o corpo abaixo da cintura e se apóia no braço direito (Figura 3A). Os pés, calçados com sandálias, apóiam-se em base irregular. A respeito da conservação, salienta-se uma rachadura na parte direita do manto e ao longo do primeiro terço da altura, bem como sinais do ataque de insetos na base da escultura.

A amostra de lenho (Figura 3D, E) foi extraída da parte posterior do embasamento, conforme indicado por setas (Figura 3B, C).

\section{Descrição anatômica}

Anéis de crescimento distintos, marcados por faixas de parênquima marginal com 3-8 células de largura (Figura 4A, B).
Vasos: arredondados ou ovais, de diâmetro médio a grande $(204 \pm 53(108-310) \mu \mathrm{m})$; solitários e em porosidade difusa (Figura 4A). Elementos vasculares com placas de perfuração simples. Pontoações intervasculares alternas $(7,1 \pm 0,9(6,2-9,2) \mu \mathrm{m})$, não ornamentadas (Figura 4F). Pontoações raio-vasculares (Figura 4D) e parênquimo-vasculares (Figura 4E), semelhantes às intervasculares, embora menores; as primeiras, de 5,6 $\pm 0,5(5,1-6,2) \mu \mathrm{m}$ de diâmetro; as últimas, de $5,7 \pm 0,8(4,1-7,2) \mu \mathrm{m}$ de diâmetro.

Parênquima axial: em faixa marginal com 38 células de largura (Figura 4A); paratraqueal escasso e apotraqueal difuso no restante do anel (Figura 4A, B). Séries parenquimáticas de 653 \pm 117 (400-900) $\mu \mathrm{m}$ de altura, compostas de 6 $\pm 1,4$ (4-9) células (Figura 4E, F).

Raios: heterogêneos, compostos de células procumbentes no corpo central (Figura 2D) e 1-2 fileiras marginais de células quadradas (Figura 4C); tri e bisseriados, em sua maioria, com poucos unisseriados (Figura 4E, F). Células radiais de contorno arredondado, em plano tangencial (Figura 4E, F); deterioração biológica, evidente em parte dos raios (Figura 4E, F).

Fibras: libriformes, não septadas e de paredes finas (Figura 4C, E, F), pouco contrastadas em relação ao parênquima axial (Figura 4A, B).

Outros caracteres: variantes cambiais, tubos lacticíferos e taniníferos, células oleíferas, células mucilaginosas, estratificação e máculas medulares, ausentes.

Análise da estrutura anatômica

$\mathrm{O}$ conjunto dos caracteres anatômicos do lenho, notadamente a faixa marginal de parênquima, bem como os poros solitários e de diâmetro médio a grande, as séries de parênquima axial com 4-8 células, os raios heterogêneos, tri e bisseriados, com fileira marginal de células quadradas, e as fibras libriformes não septadas e de paredes relativamente delgadas, permite atribuir o material investigado a 

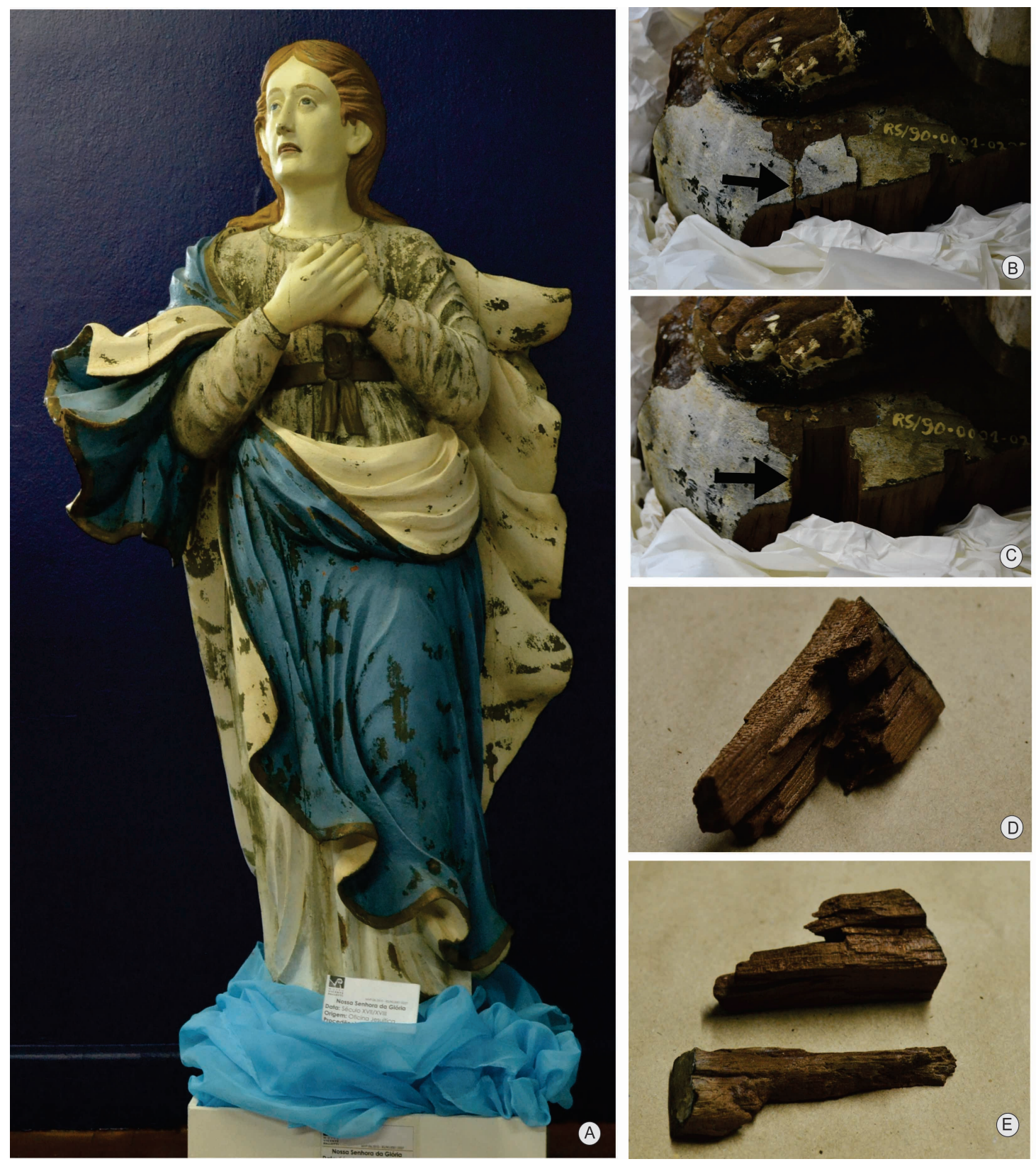

A

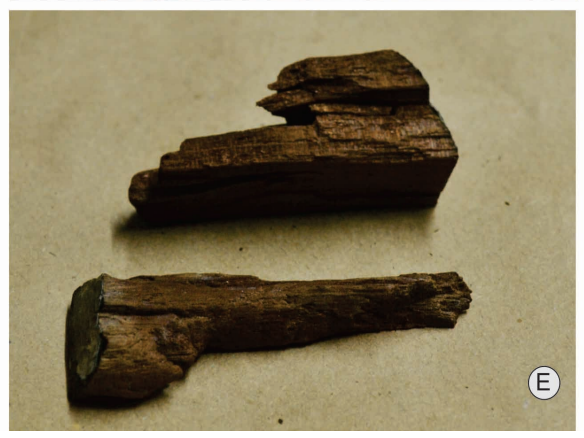

FIGURA 3 - Nossa Senhora da Gloria. A - Vista de frente. B, C - Detalhe da base, indicando o local de extração da amostra (setas). D, E - Aspectos dos fragmentos coletados. 



FIGURA 4 - Nossa Senhora da Glória; aspectos microscópicos do lenho. A, B - Faixas de parênquima marginal, poros arredondados ou ovais, em sua maioria solitários, parênquima paratraqueal escasso e apotraqueal difuso, e fibras de paredes finas (seção transversal). C - Raios de células procumbentes, com 1-2 fileiras marginais de células quadradas, parênquima apo e paratraqueal, e fibras de paredes delgadas (seção radial). D - Pontoações raio-vasculares, em detalhe (seção radial). E - Pontoações parênquimo-vasculares e raios 1-4-seriados, com sinais de deterioração (seção tangencial). F - Pontoações intervasculares e raios multisseriados (seção tangencial). 
Cedrela fissilis Vell. (Meliaceae), o popular Cedro da flora regional. A descrição realizada, em outras, palavras, corresponde ao descrito para a referida espécie botânica por Araújo (1948), Mainieri \& Chimelo (1989), Marchiori et al. (2009), Tortorelli (1956) e Tuset \& Duran (1970), entre outros autores.

\section{3 - Rei Mago}

Tombada pelo IPHAN (RS/91.001.0228) e integrante do acervo do Museu Vicente Pallotti (MVP.06.3303), a imagem do Rei Mago é de oficina jesuítica (século XVII/XVIII), foi obtida por doação (cedente desconhecido) e mede $122 \mathrm{~cm}$ de comprimento, por $115 \mathrm{~cm}$ de largura e $47 \mathrm{~cm}$ de profundidade. Feita em madeira policromada, representa uma figura masculina de corpo inteiro, em pé e posição frontal, com cabeça grande e rosto oval, levemente inclinado para baixo (Figura 5A). Os cabelos, ondulados e puxados para trás até a altura da nuca, são cingidos por tiara com desenhos geométricos em diagonal (Figura 5A-C). O rosto apresenta olhos semicerrados, nariz fino, boca pequena e fechada; o bigode, que acompanha o formato dos lábios e une-se à barba, exibe estrias em ponta maior, saindo do queixo (Figura 5A). A perna direita mostra-se flexionada e a esquerda, aberta (Figura 5A). Os pés calçam sapatos; o direito apóia-se num livro (Figura 5A). A túnica, com gola redonda, bipartida a partir do centro e cingida por faixa na cintura, tem mangas compridas e um rendilhado na altura dos ombros, que se repete na extremidade das mangas; nos punhos vêem-se dois botões no direito e quatro no esquerdo. Identificam-se três saiotes, sendo que o do meio termina em rendilhado (Figura 5A). Uma tampa, na parte posterior da imagem (Figura 5B), esconde cavidade (Figura 5C). O embasamento da escultura, relativamente pequeno, é de planta arredondada (Figura 5A-C). Nos dados de tombamento consta que a imagem é originária das Missões do Rio Grande do Sul e que procede de Cruz Alta. A respeito da conservação, além de sujidades e da perda da policromia original, faltam as pontas dos dedos, com exceção do polegar direito. As fendas na cabeça serviam, provavelmente, para a fixação de algum atributo.

A amostra de lenho para estudo anatômico (Figura 5E, F) foi extraída da parte lateral do embasamento, conforme seta (Figura 5A, D).

\section{Descrição anatômica}

Anéis de crescimento distintos, marcados por faixa de parênquima marginal com 3-7 células de largura (Figura 6A, B).

Vasos: geralmente solitários, de seção circular ou oval $(233 \pm 41(158-313) \mu \mathrm{m})$ e paredes finas. Porosidade difusa. Pontoações intervasculares alternas, não ornamentadas, de $7,1 \pm 0,8(6,2-8,2) \mu \mathrm{m}$ de diâmetro. Pontoações raio-vasculares e parênquimo-vasculares, semelhantes às intervasculares, embora menores; as primeiras, de $4 \pm 0,2(3,6-4,2) \mu \mathrm{m}$ de diâmetro (Figura 6C, D); as últimas, com diâmetro de 5,8 $\pm 0,6(5,2-7,2) \mu \mathrm{m}$ (Figura 6E).

Parênquima axial: em faixa marginal com 37 células de largura (Figura 6A, B); também paratraqueal escasso e apotraqueal difuso (Figura 6B). Séries parenquimáticas axiais de 603 \pm 136 (300-800) $\mu \mathrm{m}$ de altura, compostas por 5 $\pm 1,1$ (3-7) células (Figura 6F).

Raios: heterogêneos, com corpo multisseriado de células procumbentes e uma fileira de células quadradas, nas margens (Figura 6C, D). Os multisseriados, tri e bisseriados (até 4 células) e com $32 \pm 7$ (20-43) $\mu$ m de largura (Figura 6E, F), medem $241 \pm 66$ (95-375) $\mu \mathrm{m}$ de altura, com $11 \pm 3,8$ (5-18) células (Figura $6 \mathrm{E}, \mathrm{F})$. Tecido radial com células de seção arredondada em plano tangencial e sinais de deterioração biológica (Figura 6E, F).

Fibras: libriformes, não septadas e de paredes finas (Figura 6E), pouco contrastadas do parênquima axial em plano transversal (Figura $6 \mathrm{~A}, \mathrm{~B})$.

Outros caracteres: variantes cambiais, tubos laticíferos e taniníferos, células oleíferas, células mucilaginosas, estratificação e máculas medulares, ausentes; canais intercelulares, não observados. 

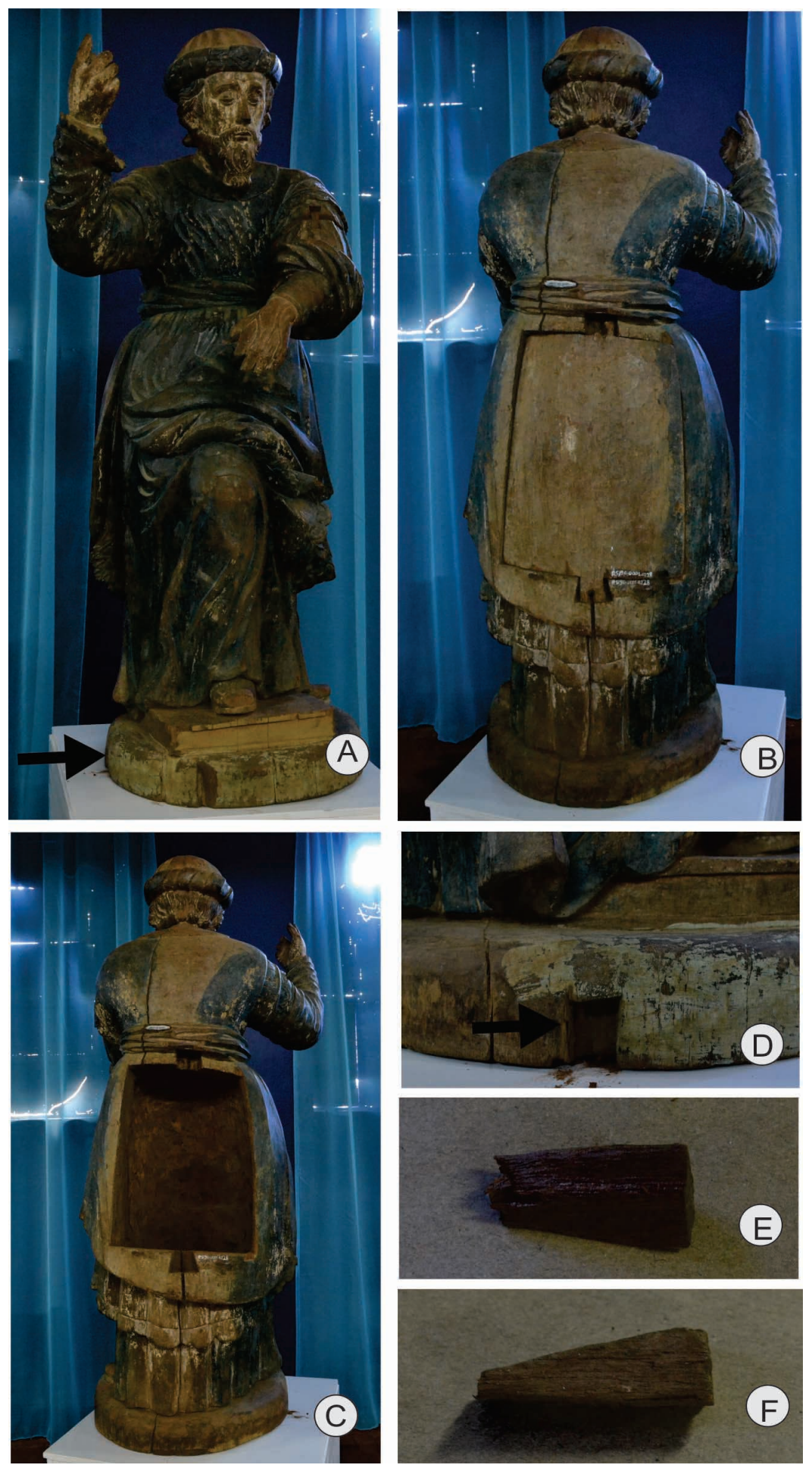

FIGURA 5 - Rei Mago. A - Vista de frente; a seta indica o local de extração da amostra de lenho. B - Vista posterior, com a tampa posta. C - Vista posterior, expondo cavidade (tampa retirada). D - Embasamento, com local de extração da amostra indicada por seta. E - Dois aspectos do fragmento de lenho coletado. 

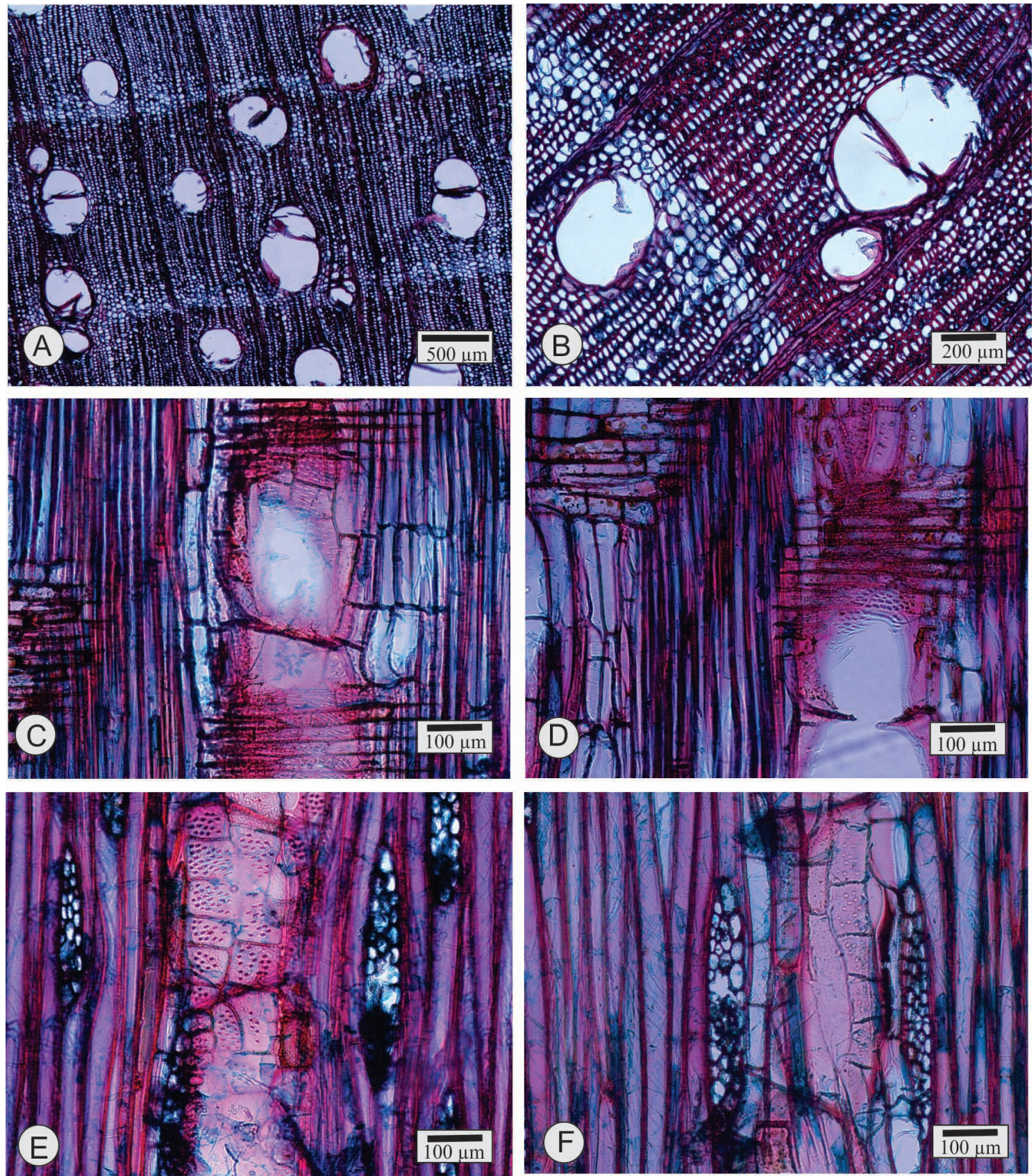

FIGURA 6 - Rei Mago; aspectos microscópicos do lenho. A - Parênquima marginal, poros solitários e geminados e fibras de paredes finas (seção transversal). B - Faixa de parênquima marginal, poros e fibras de paredes finas (seção transversal). C - Vaso com parênquima paratraqueal, células procumbentes de raio e pontoações raio-vasculares (seção radial). D - Mesmo plano anatômico e aspectos da foto anterior, destacando células quadradas nas margens de raios. E - Pontoações parêquimo-vasculares e raios 2-3-seriados (seção tangencial). F - Fibras de paredes finas e raios 2-4seriados, com sinais de deterioração (seção tangencial). 
Análise da estrutura anatômica

O conjunto de caracteres observado permite a identificação do material como Cedrela fissilis Vell. (Meliaceae), o popular "cedro" do Sul do Brasil, salientando-se, como aspectos diagnósticos: vasos de diâmetro médio a grande, em sua maioria solitários; placas de perfuração simples; parênquima axial em faixa marginal conspícua, com 3-7 células de largura; raios heterogêneos, com células procumbentes e fileira marginal de células quadradas; e fibras libriformes não septadas, de paredes finas. A descrição realizada, em outras, palavras, corresponde ao descrito para a referida espécie botânica, por Araújo (1948), Mainieri \& Chimelo (1989), Marchiori et al. (2009), Tortorelli (1956) e Tuset \& Duran (1970), entre outros autores.

\section{4 - São José}

De oficina jesuítica, autoria desconhecida e tombada pelo IPHAN (RS/91.001.0226), a imagem de São José se encontra na sala 09 do Museu Vicente Pallotti, constando, no inventário, sob o registro MVP.06.3306.

Procedente de Cruz Alta (RS) e obtida por doação em 1943 (cedente ignorado), a escultura mede $102 \mathrm{~cm}$ de altura, $62 \mathrm{~cm}$ de largura e $55 \mathrm{~cm}$ de profundidade. Representa uma figura masculina ajoelhada, com cabeça voltada para a direita e ligeiramente inclinada para baixo, com longos cabelos bipartidos, caindo encaracolados pelo ombro direito e costas, de sobrancelhas arqueadas, nariz fino, bigode seguindo a linha dos lábios e unindo-se à barba, orelhas à mostra e braços flexionados em ângulo, segurando o chapéu junto ao peito, o esquerdo pela aba e o direito pela copa (Figura 7A). Das pernas, a esquerda mostra-se genuflexa (Figura 7A); a direita, flexionada, deixa à mostra o sapato. O corpo veste túnica longa, de mangas compridas e gola redonda, bipartida (Figura 7A); a capa cai dos ombros para as costas e perna direita (Figura 7A, B). A cavidade posterior da escultura (Figura 7B) é recoberta por tampa de formato retangular, provida de dois encaixes em forma de cunha para fixação (Figura 7C). É de uma das faces adjacentes à cunha inferior (Figura 7B, seta) que se extraiu a amostra de madeira (Figura 7E, F) utilizada no estudo anatômico.

\section{Descrição anatômica}

Anéis de crescimento: distintos, marcados por faixas de parênquima marginal (Figura 8A, B).

Vasos: arredondados (Figura 8A, B), de diâmetro médio a grande $(206 \pm 48(113-305) \mu \mathrm{m})$, solitários, menos comumente em curtos múltiplos radiais (Figura 8A). Porosidade difusa. Placas de perfuração simples. Pontoações intervasculares alternas, arredondadas, de 7,7 $\pm 0,8$ $(6,6-9,3) \mu \mathrm{m}$ de diâmetro. Pontoações raiovasculares e parênquimo-vasculares, semelhantes às intervasculares, embora menores; as primeiras, de 5,5 $\pm 0,7(5,2-7,2) \mu \mathrm{m}$ de diâmetro; as parênquimo-vasculares, de $6,6 \pm 1,0(5,2-8,2)$ $\mu \mathrm{m}$ de diâmetro (Figura 8D, F).

Parênquima axial: em faixas tangenciais (margem de anéis de crescimento), bem como paratraqueal e apotraqueal difuso (Figura 7B). Séries parenquimáticas axiais de $559 \pm 122$ (300-1000) $\mu \mathrm{m}$ de altura, com $4 \pm 1,1$ (3-8) células (Figura 8E, F).

Raios: heterogêneos, de células procumbentes e com células quadradas nas margens (Figura 8C); em sua maioria tri e tetrasseriados, menos comumente bi e unisseriados (Figura 8E, F). Células radiais de contorno oval ou arredondado, em plano tangencial (Figura 8E, F).

Fibras: libriformes, não septadas e de paredes finas (Figura 8F), pouco contrastadas do parênquima axial em plano transversal (Figura 8A, B).

\section{Análise da estrutura anatômica}

As faixas tangenciais de parênquima, bem como as placas de perfuração simples, os vasos arredondados, solitários e de diâmetro médio a grande, as séries parenquimáticas com 3-8 células, os raios heterogêneos, de células procumbentes e com células quadradas nas margens, e as fibras libriformes não septadas e de paredes delgadas, permitem, em conjunto, identificar a 

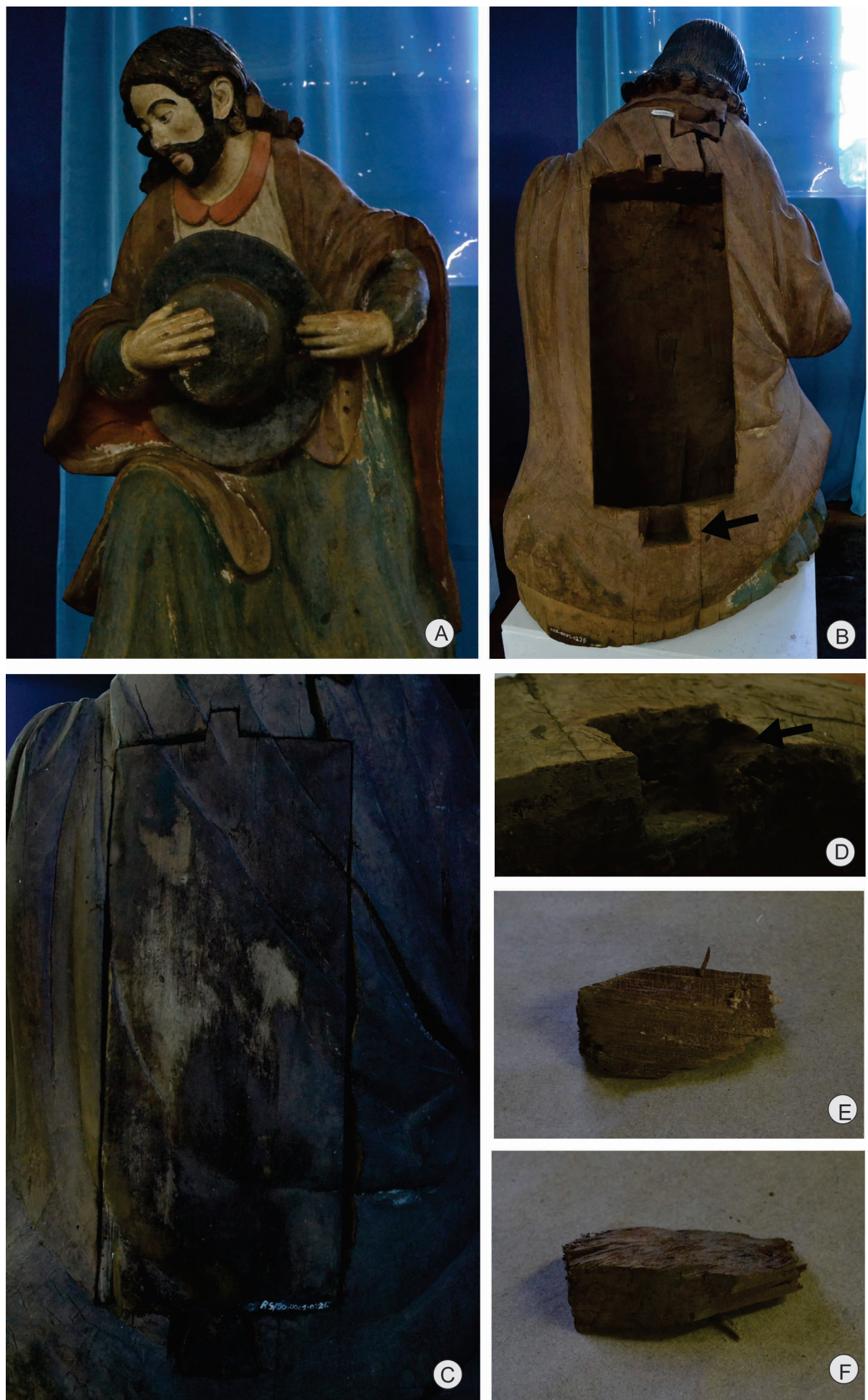

FIGURA 7 - São José. A - A escultura, vista de frente. B - Vista posterior, expondo a cavidade (tampa retirada); a seta indica o local de extração da amostra de lenho. C - Vista posterior, com a tampa posta. D - Local de extração da amostra de lenho, em detalhe. E, F - Dois aspectos da amostra coletada. 

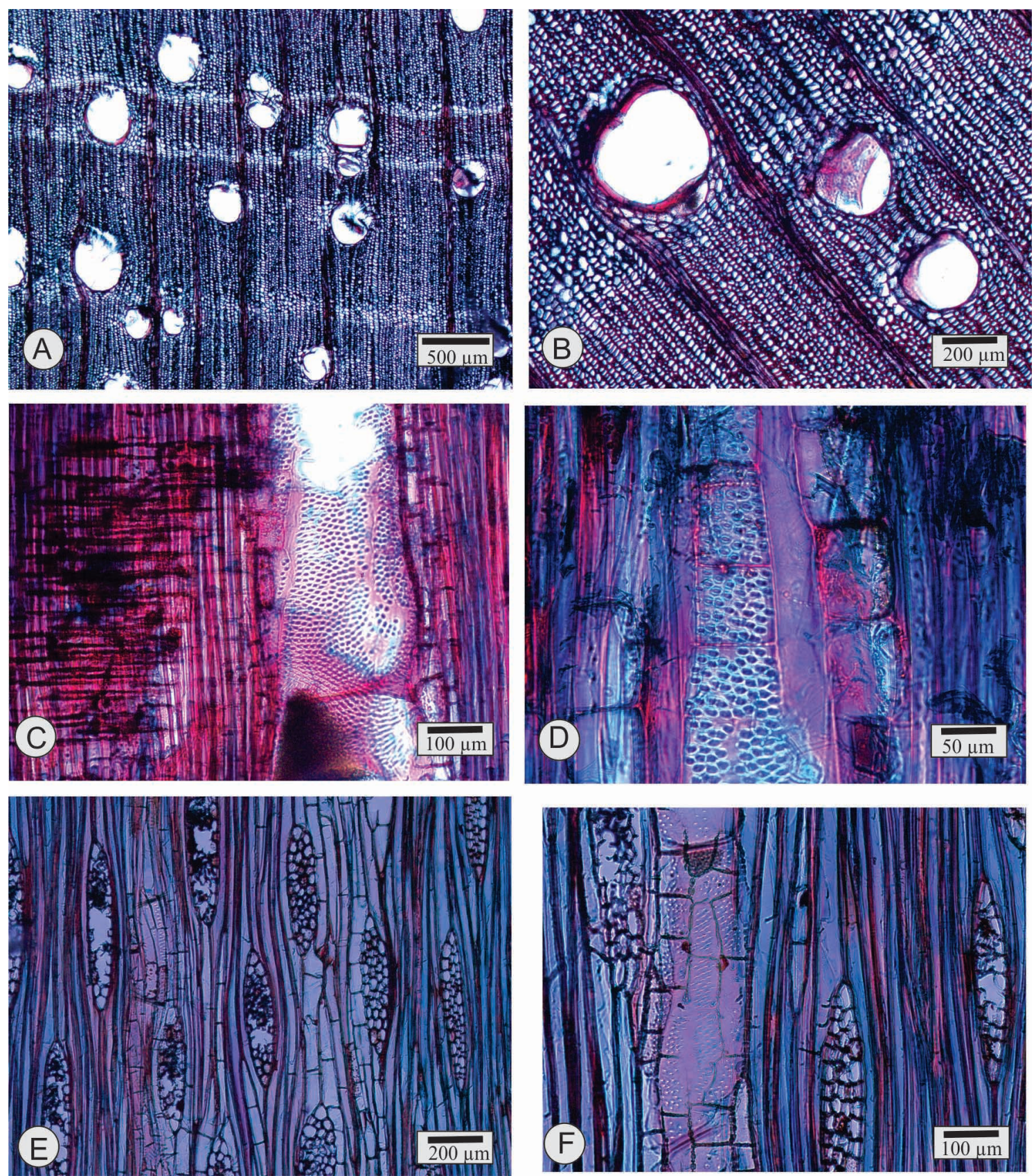

FIGURA 8 - São José; aspectos microscópicos do lenho. A - Faixas de parênquima marginal e poros geralmente solitários (seção transversal). B - Mesmos aspectos da foto anterior, salientando fibras de paredes finas. C, D - Raios, vasos e parênquima axial (seção radial). E, F - Raios multisseriados, com sinais de deterioração, séries de parênquima axial e fibras de paredes finas (seção tangencial). 
madeira como Cedrela fissilis Vell., Meliácea nativa no Sul do Brasil e popularmente conhecida como Cedro. Este conjunto de caracteres microscópicos, aliás, coincide com o referido para essa espécie botânica por Araújo (1948), Mainieri \& Chimelo (1989), Marchiori et al. (2009), Tortorelli (1956) e Tuset \& Duran (1970), entre outros autores.

\section{5 - São Roque}

Integrante do acervo do Museu Vicente Pallotti (MVP.06.3302) e tombada pelo IPHAN (RS /91.001.0229), a estátua de São Roque é de oficina jesuítica (século XVII/XVIII) e origem desconhecida. A esse respeito, a ficha de registro indica "Rio Grande do Sul", que a mesma foi doada ao museu em que se encontra pelo Pe. Caetano Pagliuca ${ }^{6}$ e que teria pertencido à antiga Igreja Matriz de Santa Maria da Boca do Monte $^{7}$, construída entre 1810 e 1814 e demolida em 1880. De madeira policromada, mede $115 \mathrm{~cm}$ de altura, por $58 \mathrm{~cm}$ de largura e $53 \mathrm{~cm}$ de profundidade (Figura 9A, B). Trata-se de figura masculina de corpo inteiro, com cabeça levemente inclinada, de cabelos longos e lisos, bipartidos a partir do centro e caindo pelos ombros e costas, e com bigode e barba (Figura 9A, B). Das pernas, a esquerda mostra-se flexionada e a direita, reta (Figura 9A). Veste túnica longa, com decorações em forma de conchas, e cinto e saiote com panejamentos (Figura 9A), deixando os joelhos à mostra. A escultura não esconde sinais de sujidade e resquícios de policromia no rosto, pescoço e embaixo do braço esquerdo. Falta a extremidade do nariz, grande parte dos

6 Nascido em Montefalciano (Província de Avellino, Campânia, Itália), em 28-03-1874, faleceu em Santa Maria, em 10-07-1957, aos 83 anos de idade. Ainda jovem (18 anos) veio para Porto Alegre, onde estudou no Seminário Diocesano, ordenando-se em 30-11-1897. De acordo com Beltrão (1979), foi "figura apostolar como até hoje não houve em Santa Maria”, destacando-se por promover a construção da Igreja Matriz da cidade (atual Catedral Metropolitana).

7 Situava-se frente à atual praça Saldanha Marinho, na área do canteiro central da Av. Rio Branco, no centro da cidade de Santa Maria. braços e pernas (Figura 9A); estas, mostram-se lascadas e carcomidas na região da panturrilha. A substância preta, observada em parte do rosto, sugere queimadura. A cavidade posterior da escultura é apenas parcialmente recoberta pela tampa (Figura 9B, C).

A amostra de madeira para estudo anatômico (Figuras 9E) foi retirada do interior da imagem (Figura 9C, D), em local escondido pela tampa.

Descrição anatômica

Anéis de crescimento: distintos, marcados por faixa marginal de parênquima com 8-10 células de largura (Figura 10A, B).

Vasos: solitários, menos comumente geminados (Figura 10A, B), de diâmetro médio a grande $(203 \pm 38(105-263) \mu \mathrm{m})$. Placas de perfuração simples. Pontoações intervasculares alternas, de 7,8 $\pm 1,1(6,2-9,3) \mu \mathrm{m}$ de diâmetro (Figura 10F). Pontoações raio-vasculares e parênquimo-vasculares, semelhantes às intervasculares, embora menores; as primeiras, de $6,2 \pm 0,5(5,2-7,2) \mu \mathrm{m}$ (Figura 10D); as parênquimo-vasculares, com $6,0 \pm 0,6(5,2-7,2) \mu \mathrm{m}$ de diâmetro.

Parênquima axial: em faixa marginal com 610 células de largura (Figura 10A, B), bem como paratraqueal e apotraqueal difuso (Figura 10B); séries parenquimáticas de $504 \pm 139$ (300-800) $\mu \mathrm{m}$ de altura, compostas por $5 \pm 1,8$ (3-8) células (Figura 10E).

Raios: heterogêneos, compostos de células procumbentes e com 1-2 fileiras marginais de células quadradas (Figura 10C, D). Em plano tangencial, com 2-4 células de largura e escassos unisseriados (Figura 10E, F). Medem $293 \pm$ 60 (137-400) $\mu \mathrm{m}$ de altura, com $12 \pm 2,9$ (5-18) células, e $50 \pm 10$ (38-75) $\mu \mathrm{m}$ de largura, com 3 $\pm 0,4$ ( 2-4) células.

Fibras: libriformes, não septadas e de paredes delgadas (Figura 10F).

Outros caracteres: variantes cambiais, tubos lacticíferos e taniníferos, células oleíferas, células mucilaginosas, estratificação e máculas medulares, ausentes. Canais intercelulares, não observados. 

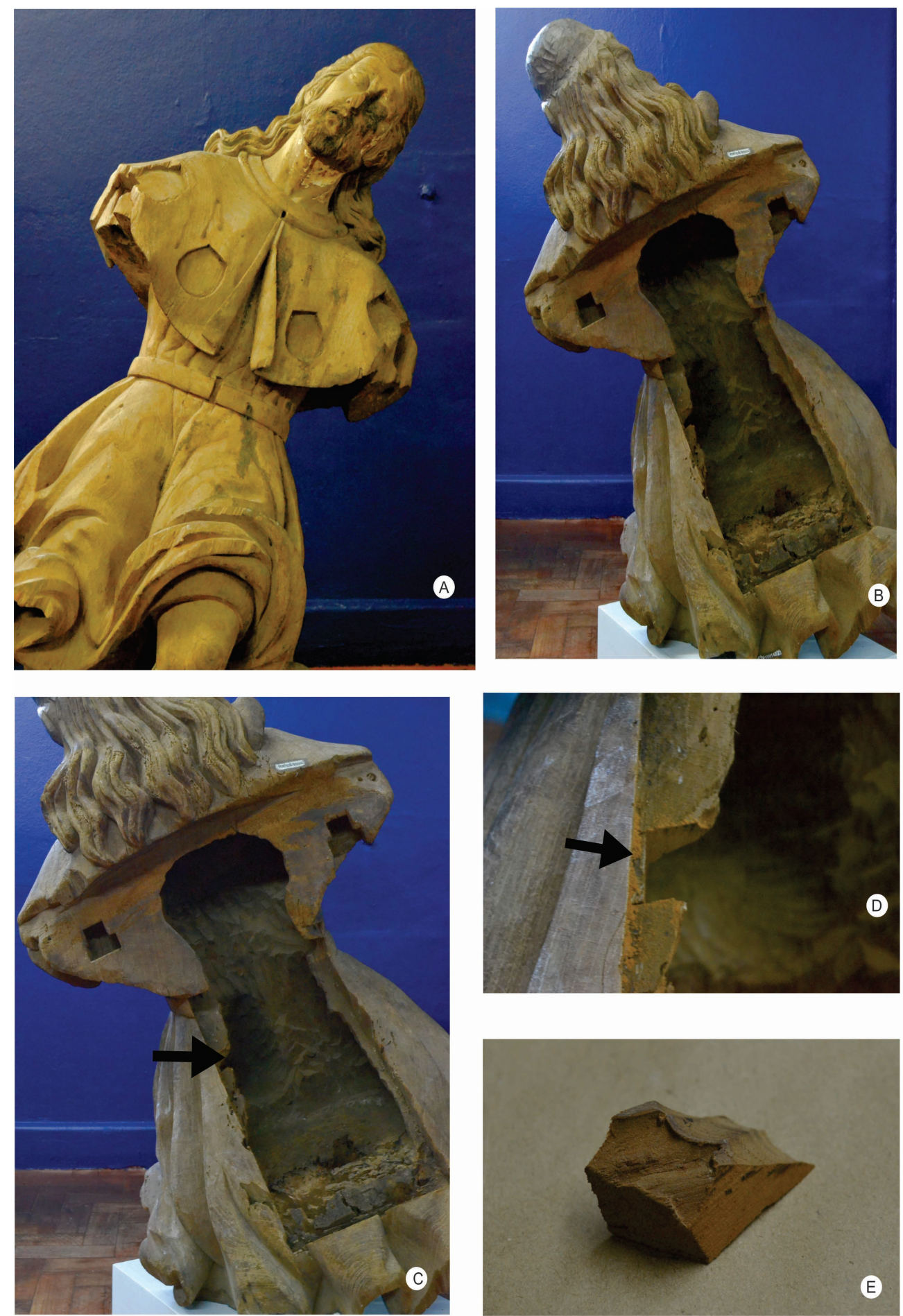

FIGURA 9 - São Roque. A - Vista frontal. B - Vista posterior, salientando a parte remanescente da tampa. C - Vista posterior, com tampa retirada, indicando o local de coleta da amostra de lenho (seta). D - Local de coleta da amostra, em detalhe (seta). E - Amostra coletada. 

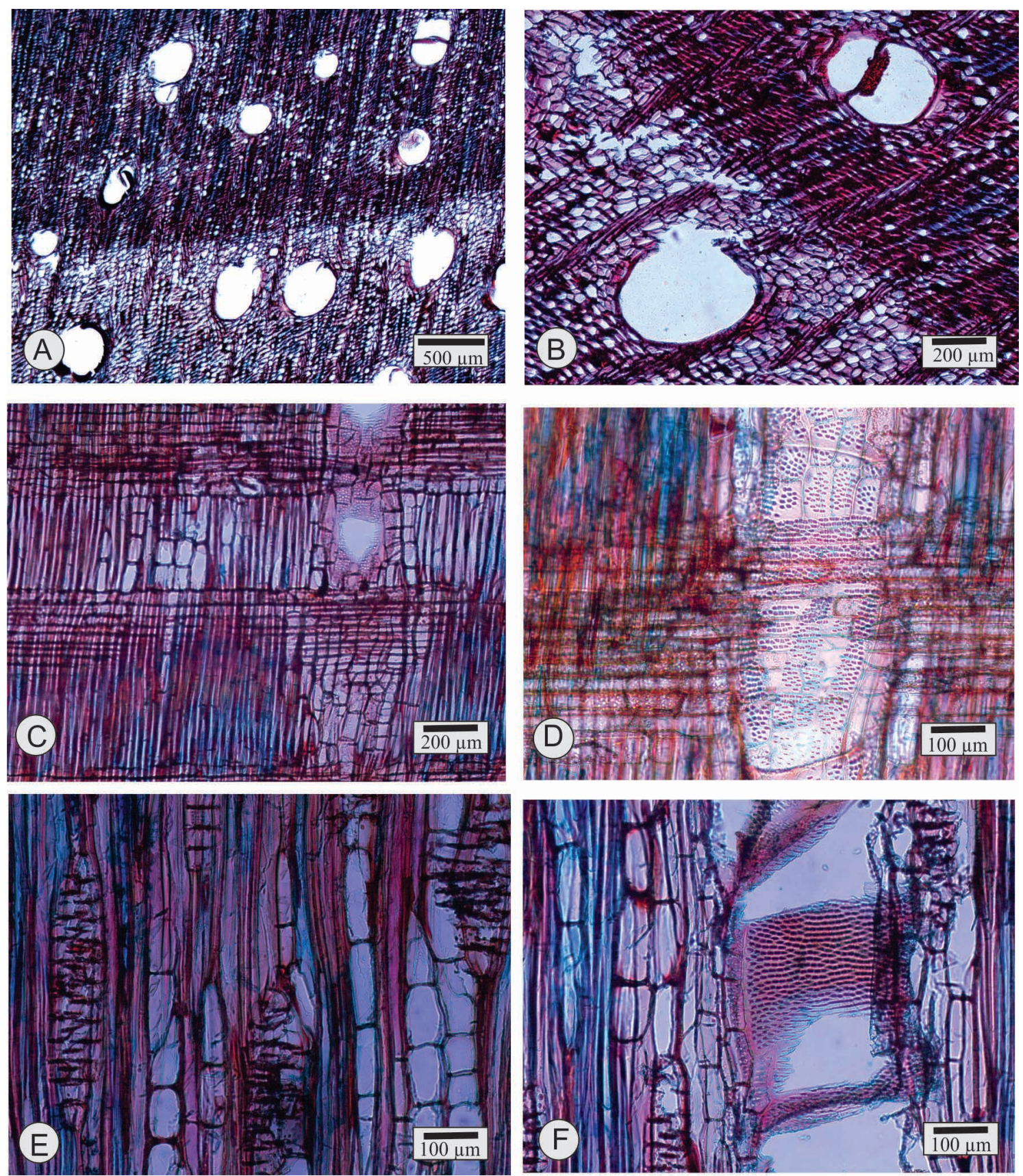

FIGURA 10 - São Roque; aspectos anatômicos do lenho. A - Anel de crescimento com larga faixa de parênquima marginal, poros médios a grandes e parênquima apotraqueal escasso e paratraqueal (seção transversal). B - Mesmo plano anatômico da foto anterior, salientando fibras de paredes finas. C - Raios heterogêneos, com células quadradas nas margens, parênquima axial e fibras de paredes finas (seção radial). D - Mesmo plano anatômico e detalhes da foto anterior, salientando pontoações raio-vasculares. E - Raios, fibras e parênquima axial, em seção tangencial. F-Pontoações intervasculares, em detalhe (seção tangencial). 
Análise da estrutura anatômica

A identificação do lenho como "Cedro" (Cedrela fissilis Vell.) baseia-se no seguinte conjunto de caracteres microscópicos: parênquima em larga faixa marginal, além de paratraqueal e apotraqueal difuso; placas de perfuração simples; séries parenquimáticas axiais com 3-8 células de altura; raios heterogêneos de células procumbentes, com 1-2 fileiras marginais de células quadradas; e fibras libriformes não septadas e de paredes delgadas. A diagnose corresponde, integralmente, ao descrito por Araújo (1948), Mainieri \& Chimelo (1989), Marchiori et al. (2009), Tortorelli (1956) e Tuset \& Duran (1970), para a referida Meliácea.

\section{DISCUSSÃO}

Madeira leve até moderadamente pesada $\left(0,55 \mathrm{~g} / \mathrm{cm}^{3}\right)$ e de boa estabilidade dimensional, o Cedro (Cedrela fissilis Vell.) é macio ao corte, muito durável em ambiente seco e de fácil trabalhabilidade, proporcionando superfície lisa e uniforme, com boa absorção de pigmentos e polimento. Além disso - e devido a suas excelentes propriedades físico-mecânicas -, essa madeira é a mais versátil do Sul do Brasil, indicando-se para esculturas e obras de talha, para instrumentos musicais, bem como para construção civil, naval e aeronáutica (Marchiori \& SchulzeHofer, 2008).

O que chama atenção, no contexto histórico, é que os padres jesuítas, sem maiores conhecimentos da flora euxilófora americana, souberam valer-se das melhores espécies para cada uso ou finalidade: é o que se comprova na estatuária, que foi realizada, majoritariamente, em madeira de cedro, caso das três esculturas do Museu Sacro de Santa Maria (Marchiori \& Machado, 2017), bem como das imagens de São Lourenço Mártir (Marchiori \& Schulze-Hofer, 2009c), Santo Estanislau Kostka (Marchiori \& Schulze-Hofer, 2010b) e Nossa Senhora das Dores (Schulze-Hofer \& Marchiori, 2010), integrantes do Museu das Missões (São Miguel das Missões, RS). Até o momento, apenas a imagem de São José (Marchiori \& Schulze-
Hofer, 2009a) destoa neste conjunto, por ter sido realizada em madeira de conífera (Araucaria angustifolia).

A respeito do Cedro, já o Pe. Antônio Sepp (1655-1733), fundador da Redução de São João Batista e pioneiro na fundição de ferro no Rio Grande do Sul, reconhecia esta espécie como a preferida para todas "las cosas que han de tener oro y plata y para todo género de tablas y canoas" (Lamego, 1940). Foi, precisamente, essa a madeira escolhida pelo Pe. Sepp para construir o Sacrário (ou Tabernáculo) de sua Igreja de São João Batista, nas Missões Orientais do Uruguai (atual Rio Grande do Sul), bem como uma capela ortogonal construída junto ao referido templo missioneiro, e que foi inspirada no "plano da Capela de Oettingen” (Sepp, 1972).

O presente trabalho, ao confirmar que as cinco esculturas em estudo foram feitas em madeira de cedro, comprova, ao mesmo tempo, que as mesmas são de fatura americana, não européia.

No tocante à autoria das esculturas, o mais provável é que não se consiga resultado positivo, por maiores que sejam os esforços envidados, visto serem numerosos os escultores jesuítas e artífices indígenas citados na História da Arte Missioneira. Além disso, as obras produzidas no período não possuem, como regra, qualquer registro ou comprovação documental. É por este motivo que assertivas neste sentido resultam muito discutíveis, para dizer o mínimo.

\section{REFERÊNCIAS BIBLIOGRÁFICAS}

ARAÚJO, P.A. de M. Fichas dendrológicas, comerciais e industriais de madeiras brasileiras. An. Bras. Econ. Florestal, Rio de Janeiro, v.1, n. 1, p. 345-555, 1948.

BACKES, A.; NARDINO, M. Nomes populares e científicos de plantas do Rio Grande do Sul. São Leopoldo: Ed. Unisinos, 2001. 202 p.

BELTRÃO, R. Cronologia histórica de Santa Maria e do extinto município de São Martinho. Canoas: La Salle, 1979. 582 p. 
LAMEGO, A. Os Sete Povos das Missões. Revista do Serviço do Patrimônio Histórico e Artístico Nacional, Rio de Janeiro, n. 4, p. 75, 1940.

MAINIERI, C.; CHIMELLO, J.P. Fichas de características das madeiras brasileiras. São Paulo: IPT, 1989. $418 \mathrm{p}$.

MARCHIORI, J.N.C.; MACHADO, P.F. dos S. Identificação anatômica do lenho de três esculturas do Museu Sacro de Santa Maria, RS. Balduinia, Santa Maria, n. 60, p.11-28, 2017.

MARCHIORI, J.N.C.; MACHADO, P.F. dos S. Anatomia do lenho de esculturas do Museu Vicente Pallotti (Santa Maria, RS, Brasil). 1 - Descrição e identificação anatômica do "Menino". Balduinia, Santa Maria, n. 62, p. 9-17, 2018.

MARCHIORI, J.N.C.; MUÑIZ, G.I.B. de; SANTOS, S.R. dos. Madeiras do Rio Grande do Sul. 1 Descrição microscópica de 33 espécies nativas. Santa Maria: [s.n.], 2009. 80 p.

MARCHIORI, J.N.C.; SCHULZE-HOFER, M.C. O uso da madeira nas Reduções Jesuítico-Guarani do Rio Grande do Sul. 3 - Imagem de São José. Balduinia, Santa Maria, n. 14, p. 1-4, 2009a.

MARCHIORI, J.N.C.; SCHULZE-HOFER, M.C. O uso da madeira nas Reduções Jesuítico-Guarani do Rio Grande do Sul. 5 - Fragmento de madeira procedente de escavações arqueológicas no átrio da Igreja de São Lourenço. Balduinia, Santa Maria, n. 16, p. 1-5, 2009 b.

MARCHIORI, J.N.C.; SCHULZE-HOFER, M.C. O uso da madeira nas Reduções Jesuítico-Guarani do Rio Grande do Sul. 6 - Imagem de São Lourenço Mártir. Balduinia, Santa Maria, n. 17, p. 7-10, 2009c

MARCHIORI, J.N.C.; SCHULZE-HOFER, M.C. O uso da madeira nas Reduções Jesuítico-Guarani do Rio Grande do Sul. 9 - Pilar do Colégio de São Miguel Arcanjo. Balduinia, Santa Maria, n. 20, p. 5-9, 2010a.

MARCHIORI, J.N.C.; SCHULZE-HOFER, M.C. O uso da madeira nas Reduções Jesuítico-Guarani do Rio Grande do Sul. 10 - Imagem de Santo Estanislau Kostka. Balduinia, Santa Maria, n. 21, p. 29-32, 2010 b.

RECORD, S.J.; HESS. R.W. Timbers of the New World. New Haven: Yale University Press, 1943. 640 p.

SEPP, A. Viagens às Missões Jesuíticas e Trabalhos Apostólicos. São Paulo: Livraria Martins Editora / Editora da Universidade de São Paulo, 1972, p. 175.

SHULZE-HOFER, M.C.; MARCHIORI, J.N.C. $O$ uso da madeira nas Reduções Jesuítico-Guarani do Rio Grande do Sul. Porto Alegre: IPHAN, 2008, $80 \mathrm{p}$.

SCHULZE-HOFER, M.C.; MARCHIORI, J.N.C. O uso da madeira nas Reduções Jesuítico-Guarani do Rio Grande do Sul. 8 - Mísula do alpendre do Colégio de São Luiz Gonzaga. Balduinia, Santa Maria, n. 19, p. 14-18, 2009.

SCHULZE-HOFER, M.C.; MARCHIORI, J.N.C. O uso da madeira nas Reduções Jesuítico-Guarani do Rio Grande do Sul. 11 - Imagem de Nossa Senhora das Dores. Balduinia, Santa Maria, n. 22, p. 31-34, 2010.

TORTORELLI, L.L. Maderas y bosques argentinos. Buenos Aires: ACME, 1956. 910 p.

TUSET, R.; DURAN, F. Descripción y clave macroscópicas de maderas comerciales en Uruguay. Montevideo: Universidad de la Republica, 1970. 63 p. (Bol. n. 114). 